\title{
ISLAM AND NATIONALISM: The Role of the Universitas AI Washliyah In the Era of Post Independent 1950s
}

\author{
Faisal Riza \\ Universitas Islam Negeri Sumatera Utara \\ J1. Willem Iskandar Pasar V Medan Estate, Medan, Sumatera Utara, 20371 \\ e-mail: faisalriza@uinsu.ac.id
}

\begin{abstract}
This article attempts to explore the role of Al Washliyah University in the trajectory of modern Indonesian history, especially regarding the Islamic style they developed, the Islamic scientific authority built by both scholars and their teachings. In addition, this article examines the strategic position of the university in the 1950s sociopolitical setting in North Sumatra. This study is a historical study with a political sociology approach by prioritizing archival records, published historical sources, and making greater use of a wide range of oral material in the form of interviews. The results of this study indicate that UNIVA has bridged and developed the two main streams of public debate since the independence era and even now, namely regarding Islam and nationality. The thoughts of the founders have strengthened the integration between Islam and nationality in a formula to build a nation and a generation. Then, this affirmation is seen as important as the main argument in this article which allows the opening of a dialogue about how the Islamic scientific tradition that was built and developed by UNIVA scholars as a foundation for Islamic educators, actors of Islamic universities in promoting democratization and nationality, creating social cohesion.
\end{abstract}

Keywords: UNIVA, Islamic higher education, Islamic authority, nationalism 


\section{Introduction}

Historically, the existence of Indonesian Islamic organizations in the early 20th century was a response to the rise of Islam in many parts of the world with a Muslim majority and to prepare the people for independence from Western imperialism. Here, religion as the principle of organizational movement plays a role in inspiring conversations and debates about how to remove colonial oppression and find a better alternative world order. ${ }^{1}$ This phenomenon occurs in many regions in Indonesia, such as Muhammadiyah in Yogyakarta 1912, NU 1926 in Jombang, East Java. In 1930 there was Al Khairat in Central Sulawesi, Nahdlatul Wathon in Lombok NTB, and Al Jam'iyatul Wasliyah in North Sumatra. The general conception of Islamic mass organizations in Indonesia includes not only the administration of the infrastructure of a network of mosques, and affiliated religious gatherings, but also children's play groups, social enterprises, fatwa boards and auxiliary organizations for women, youth and students, more from that there are major basic education to higher education provision. ${ }^{2}$ Likewise with Al Washliyah, who since its inception was consistent in advocating for the life of Muslims in North Sumatra. All forms of work of this organization are fully directed at several strategic matters such as countering reformist Islamic movements such as $\mathrm{NU}^{3}$ confronting the Christianization movement, and preparing for Indonesian independence. Here it can be considered that the scholars of Al Washliyah never imagined that they would struggle to create a form of an Islamic state like a caliphate, but they were republican, patriotic scholars who both loved their religion and their people as well as their nation.

The development of globalization, an increase in the degree of democratization, the growth of a new middle class economy, and the rapid development of internet technology and digitalization, 
apart from providing practical advantages in the nation's civilization, also has an unfavorable impact on the country. For example, Islamic transnationalism movements that have entered massively in the last few decades have reopened the discourse on the relationship between religion and the nation state. Therefore, one of the central points in dynamizing this discourse is reading the role of the university in creating agents of modernization and social change in society. The study of higher education explores the role of state Islamic higher education PTAIN and their role in transformation and social cohesion. Kraince, Azra, Amin Abdullah, were among those reviewers. Elaboration on the role of Islamic higher education institutions that were built by Islamic organizations even before independence was still minimal. Whereas research on this matter is very important to look back at how the Islamic landscape in Indonesia is, how their role was in the post-independence era, how the narrative of the struggle of Muslims outside Java.

There are several studies which elaborate UNIVA, firstly, Nukman Sulaiman, et al., Lustrum VI Universitas Al Washliyah 18 Mei 1958-18 Mei 1988. ${ }^{4}$ This book, published in 1988, summarizes a lot of information about the activities and achievements of the university since its inception. However, this document is a manager's subjective record which is not designed to provide a broader explanation of the socio-political background and structure outside the organization that directly or indirectly affects the running of the institutional agenda. The other study is from M. Hasballah Thaib, who is a third generation figure from UNIVA and has been the Chancellor there. Hasballah wrote the historical fact that UNIVA had once been an educational institution for producing Ulama in North Sumatra, the impact of which is felt even today. ${ }^{5}$ However, Hasballah did not elaborate much on the sociological and political contexts that were important 
for why UNIVA's role was so significant at that time. Furthermore, a study by Rita Zahara, ${ }^{6}$ which in her dissertation at UIN North Sumatra with a historical approach, she also explained how the development of these higher education institutions in contemporary times. However, Rita, once again, elaborated more on the role of the historical field of education, not much on the outside factors such as social, economic, cultural and political structures. Siddik and Rosnita ${ }^{7}$ explain about the significant role of Al Washliyah and their educational institution in developing public literacy and supporting national education program. Lastly, Dedi Iskandar Batubara in his study about ethics of lecturers in Al Washliyah University. In this study he explore much about the ethic of Islam that colouring scholars and lecturers in $\mathrm{Al}$ Washliyah University.

From the above discussion on the survey of previous studies, it can be seen that there is a gap that could be filled as study development in this area. It is important to consider that Medan is a city of a large plantation industry since the turn of the century, plantations have greatly influenced people's lives here and it needs clarification, the sociological structure in reading history in this case UNIVA is important so its development can be interpreted not only as the development of educational institutions but more from that the socio-political development of the Islamic community in Medan, the development of the nation state. I emphasize here that the study of UNIVA in a sociological and political approach is relevant to fill the void in the study. In addition, with this approach, another presentation will be obtained about the history of UNIVA and the influence of its role in society in North Sumatra.

This article aims to fill in the gaps in the discourse regarding the role of the higher education institution specifically to describe the social role of a university in Medan, North Sumatra, namely 
Al Washliyah University (UNIVA) by examining some of the work of its founding figures in strengthening Islamic scholarship, producing Ulama and strengthening the Indonesian nationality. The choice of UNIVA is considered through the historical fact that this university is the second Islamic university after UISU, which is strongly affiliated with Masyumi in North Sumatra. This political context is very important to see when we refer to the background of Indonesia and especially North Sumatra in the 1950s, when many historians have the view that the 1950s were the dark years of Islamic politics in the course of the Indonesian nation, namely the strengthening of tensions between the government and Islam. Many Masyumi leaders were accused of being supporters of the rebellion and anti-national unity.

However, it is also important to consider that the 50s was an era in which Nationalism was victorious. ${ }^{8}$ Nationalism as a cohesive force that binds the archipelago is at its zenith. That year saw a very easy transition from a federation of 16 states to a unitary republic. What is interesting about this incident is in the process, when informal leaders at the local level, kyai, ulama and their organizations, and traditional leaders actually played a significant role in unitaryism. This fact was based on their political orientation which was largely shaped by a sense of belonging to Taufik Abdullah's national revolution. ${ }^{9} 1950$ also saw the launch of a new national identity that was outwardlooking, expressed optimism and confidence.

\section{Methodology}

This study is a historical study using a political sociology approach. The historical method consists of heuristics, criticism, interpretation, and historiography. The historical method is a method used to find facts in historical sources and present 
them in written form. Heuristics is the stage of collecting sources and historical records that are related to the research topic. In this context, sources related to the topic of this study are important archives about UNIVA that I have collected, explored and analyzed. Apart from archives, there are also documents from publications in the form of magazines and bulletins related to research data. Then, several archives can also be found in the collection of the National Archives of the Republic of Indonesia (ANRI) through the classification of the Archives of the State Secretariat of the Prime Minister's Cabinet. To complete the triangulation of data, I conducted interviews with a number of figures who were strongly associated with the founders of Al Washliyah University, besides that I also spoke with the current Chancellor of UNIVA, and with several functional lecturers there.

Furthermore, the method of criticism is the stage of source selection and fact gathering. Here the physical condition and characteristics captured by the senses are assessed and then a selection is made regarding the content, information, and facts in the historical source or record. In addition, the Interpretation stage is also carried out in which the compilation of facts and interpretations with existing concepts and theories are woven into the imagination of the researcher. Finally, the researcher entered the historiography stage, namely the writing stage of the interpretation results.

\section{Results and Discussion}

\section{AI Washliyah and Ummah in North Sumatra 1950s}

The presence of universities cannot be understood neutrally because such institutions, especially those founded by scholars and their organizations, certainly contain ideological narratives. This section explores the facts of the socio-political history of 
Muslims in North Sumatra, where the founding scholars of $\mathrm{Al}$ Washliyah founded Al Washliyah University accompanied by socio-political turmoil that did not entirely benefit Muslims, this 1950s setting is useful to obtain various facts that explain why then in turn, the presence of UNIVA is very strategic for Muslims with a formula for moderate thinking, in the form of Islam and nationality.

The historical narrative of North Sumatra cannot be separated from the role of Islam since the Islamization of the kingdom of Aru or Haru in the mid-17th century, the Sultanate of Deli, until the presence of modern Islamic organizations in the early 20th century shows a strong Islamic trend. One of the Islamic organizations that was born in Medan is Al Jam'iyatul Washliyah or abbreviated as Al Washliyah. ${ }^{10}$ This organization was founded by several ulama and students such as Ismail Banda, ${ }^{11} \mathrm{M}$. Arsjad Th. Lubis, ${ }^{12}$ Abdurrahman Sijhab, ${ }^{13}$ Yusuf Ahmad Lubis, ${ }^{14}$ Shaykh Muhammad Yunus, Shaykh Hasan Ma'sum, Shaykh Mahmud Ismail Lubis, on November 30, 1930, ${ }^{15}$ with the Ahl Sunnah wa al-Jamâ'ah theology or with Ashariyah theology, ${ }^{16}$ and is oriented towards strengthening the Shâfíi ischool of thought. ${ }^{17}$ Al Washliyah in the early days emerged as a response to three things: first, Western colonialism, ${ }^{18}$ rife Christianization, and rivals of modernist Islam. ${ }^{19}$ As an organization that was founded in the era of the independence struggle movement, their ulama fought for independence, ${ }^{20}$ they established schools as a means of reinforcing the teachings they believed to strengthen Islamic faith and dispel Islamic modernism, ${ }^{21}$ and they preached to the Porsea valley and Karo highlands for the agenda of Islamization and fighting Christianization. ${ }^{22}$

The spirit of this movement started from the field of education where Al Washilyah established many educational institutions in various regions in North Sumatra to reinforce the ideology of the Ahl al-Sunnah wa al-Jamâ'ah, ${ }^{23}$ educate the life of the 
ummah, and meet the availability of human resources for society and the state. In the early days they did a lot of religious studies, especially in the Al Qismul 'Aly (high school level) program, ${ }^{24}$ as the program to prepare becoming ulama. ${ }^{25}$ Furthermore, in the development of education policy, they later modernized and made a number of curriculum adjustments to respond to government policies. In an effort to empower Muslims in the field of education of Al Washliyah and their ulama, they see the importance of playing women equally with men. ${ }^{26}$ Their ulama established a women's wing organization here called Muslimat Al Washliyah in 1936, believing that involving the role of women in education and empowering the ummah would help accelerate the nation's independence. ${ }^{27}$

In the post independent era, there are several phenomena in the political arena as reported by some literature such as Feith, ${ }^{28}$ Ricklefs, ${ }^{29}$ and Taufik Abdullah. ${ }^{30} 1950-1957$ was the era of constitutional democracy including the first elections of 1955, and also after 1957 the era of guided democracy, 19571958 the era of regional upheaval, political crisis, the increasing of authoritarian rule, the rising position of communism in politics, social and culture, and nationalization of foreign asset and companies.

North Sumatra in the 1950s was a miniature of the multicultural society in Indonesia. Its position as one of the developing industrial areas during the colonial period resulted in a complex social structure. Migration of contract coolies "koeli koentrak" from various ethnic groups came here which was known as "Deli", some of these migrants also worked as professionals, teachers and doctors. In 1939, HAMKA, a popular cleric at that time, had published the novel "Merantau ke Deli", ${ }^{31}$ where in the book he recorded the plurality of cultures in the land of Deli and the bitterness of the life of the coolies. In addition, 
Hamka imagines that the socio-cultural diversity here can be the forerunner of the Indonesian nation in the future. In the field of culture, Medan as the capital of North Sumatra can be said to be more cosmopolitan compared to Jakarta, especially when the film industry and the printing of comics, literature and the like have close contacts with Singapore and Penang.

From 1952 to 1955, it can be said to be one of the regions that determined the flow of national politics because the events that occurred in North Sumatra affected the government and parliament in the central government. For example, in the span of the decade of the 50s, North Sumatra faced three crucial issues that were critical to the political situation, including land disputes, political elite conflicts, and the problem of oil exploration in Pangkalan Brandan, Langkat. First, the plantation industry which had developed in the Dutch colonial era left an acute problem surrounding land disputes in North Sumatra, then created two conflicting attitudes, those who supported giving land to foreign capital and those who did not. ${ }^{32}$ Apart from plantations, there is an oil mine in Pangkalan Berandan, Langkat, with a similar case. In these two major national cases the political position of the Muslims, in this case represented by Masyumi, is in a pro-foreign capital position on the grounds that the Indonesian people are not yet fully able to manage natural resources in a modern way. The gap between traditional rulers and society made radical ideology grow massively in the period from 1930 to 1945, both Islamism and Communism. At its peak, there was a social revolution that overthrew the sultanate in East Sumatra in 1946. ${ }^{33}$

For a long time, Medan and several areas of North Sumatra, especially along the east coast and southern part of Tapanuli, were Muslim enclaves. So that here Masyumi was the party that got the most support in the 1955 election. $^{34}$ Meanwhile at the 
national level, the party that won the 1955 election was PNI. This dominance at the national level made PNI begin to reduce the influence of its competitor Masyumi in various regions, including North Sumatra. Strategic positions in regional government were left to people, at least not Masyumi sympathizers. Masyumi reacted to the government's treatment by making political maneuvers. ${ }^{35}$ They held conferences of Alim Ulama on 11-13 April 1953 in Medan. The participants came from various Islamic groups affiliated with Masyumi. The results of the congress emphasized the people of North Sumatra to choose candidates from Islamic parties or those who supported Islam. Islamic organizations in North Sumatra such as PUSA (Persatuan Ulama Seluruh Aceh), Front Mubaligh, and Al Jam'iyatul Washliyah announced the results of the congress to the public.

This series of events led to Masjumi's position, which was considered by the people as an antagonist. ${ }^{36}$ For example, in a land dispute case, Masyumi was involved in the Tanjung Morawa Incident. In the case of the Aceh armed conflict, Masyumi, in his neutral stance, was seen as supporting Daud Beureueh's rebellion. On the North Sumatra oil mining issue, the Masyumi ministers did not have a firm stance on the case. The first party to associate Masjumi's political attitudes as a pro-foreign form was the PKI. In November 1954, the PKI agreed on Pancasila as the state ideology. This is certainly a weapon for Masyumi's political opponents to corner Masyumi in North Sumatra. The political position of the Muslims in this case Masyumi continues to be in an unfavorable situation: Starting from being considered pro foreign, not supporting Pancasila, and supporting rebellion. All of these are conditions which in turn affect the relationship between the government and Muslims in other fields such as in education. 
Al Washliyah since its inception has concentrated on developing educational services for Islamic family members in North Sumatra. They voluntarily established a number of elementary schools (Ibtidâiyah), junior high schools (Tsanâwiyah), and high schools (Al Qismul 'Aly), in areas ranging from Medan, Perbaungan, Serbelawan, Pematang Siantar and Labuhan Bilik. In the first congress in 1936, when it was in sync with the spirit of empowering women in various regions, the issue of the use of the headscarf in public spaces was raised. ${ }^{37}$ Here the $\mathrm{Al}$ Washliyah organization encourages the discourse on the use of hijab for Muslim women not only in Al Washliyah schools, more than that they suggest to other schools to provide support for the use of headscarves in public schools for Muslim women. The general announcement was issued in 1937 which was a follow-up to the results of the first congress in 1936. In the document it was recorded that the congress participants were present at around $5000 \mathrm{Al} \mathrm{Washliyah}$ students from various regions, dozens of schools, and hundreds of teachers. In 1938 the Al Washliyah schools had completed 58 elementary students around Medan, Pematang Siantar, Serbelawan, and Labuhan Bilik. In addition to special educational institutions for men, in 1938 this organization also established a special madrasa for women in Padang Bulan and 1940 in Medan Petisah. In subsequent developments, when many alumni from various Al Washliyah schools needed higher education institutions. This is one of the main reasons for the proposed establishment of the Al Washliyah University, and the explanation about this would be explained in the next section.

\section{UNIVA in the Early Days}

The establishment of UNIVA was between the two major political struggles after the independence of the Republic of Indonesia. First, the strengthening of the political spirit of 
Islam which tends to confront the government which results in accusations of anti-nationalism and a unitary state; second, the "Indonesianization" of foreign companies and land reforms promoted by the PKI. This crisis caused many people from the interior to move to Medan for various reasons such as work, avoiding the dangers caused by the war of independence, the bloody social revolution of 1946, and the national army chasing illegal encroachers on plantation land in the fifties. In addition, their movement to cities is caused by their motivation to get a better education. ${ }^{38}$ Students who have graduated from Al Washliyah colleges in the regions and students from Islamic boarding schools need university institutions to continue their education. The orientation of a new nation in developing humanity is continuously being carried out, and one of them is the need for the availability of higher education institutions which are considered urgent because the state needs the best undergraduate level sons and daughters to fill strategic positions in the government bureaucracy.

Several studies of tertiary institutions and their role in social change illustrate how religious identity emerges in social and historical contexts and show that its development is a variable rather than a static outcome. Islamic higher education in its development carries more missions, including ideology and politics. Said and Elangkovan said the university serves as an educational agency to prepare graduates of noble character who will participate in religion and national development. ${ }^{39}$ Lukensbull recorded how PTKIN (state Islamic religious college), in its dynamics, works to help the state and Muslims negotiate what Islamic values are desired in the administration of citizenship. ${ }^{40}$ In 1945, a private institution called Sekolah Islam Tinggi was founded in Jakarta. Later this institution moved to Yogyakarta and became the Islamic University of Indonesia (UII). The Faculty 
of Religion at UII became a government institution in 1950, called the State Islamic College (PTAIN; National Islamic College). In 1957, the government also established the Religious Science Service Academy in Jakarta. In 1960, the two institutions merged into IAIN with a campus in Yogyakarta offering the faculties of Ushuluddin (Islamic theology and comparative religion) and Sharia (Islamic law) and a campus in Jakarta offering education and history faculties. Historically, the largest faculties at IAIN, across all campuses, are Sharia (Islamic law) and Tarbiyah (education). These two faculties provide judges, officials, and teachers for Indonesia's bureaucracy and religion.

In North Sumatra, since the beginning of independence until the 1970s, the number of alumni of madrasah and Islamic boarding schools who wish to continue their studies at higher education has increased. The students generally go to existing Islamic universities such as UISU and UNIVA. The transition of Islamic higher education institutions which were managed by Islamic organizations only occurred in the 1970s. The formation of IAIN North Sumatra in 1973 was a natural development of the advancement of education in North Sumatra. From a historical perspective, the existence of State Islamic higher education institutions is based on two factors. First, that there was no Islamic higher education institution at that time in North Sumatra Province. Second, the growth of madrasah, pesantren, and educational institutions equivalent to secondary schools is growing rapidly in this area, which in turn requires the existence of higher education institutions.

The promotion of the state is getting stronger gradually because PTAIN is considered an important institution in creating an agency that bridges the state and Islam. Along with the strengthening of PTAIN in North Sumatra, the role of UNIVA has gradually decreased, especially in terms of producing ulama 
and civil servants in the religious bureaucracy. Azra considers the contemporary PTAIN development to be optimistic but faces a dilemma. The politics of higher education in Indonesia is experiencing budgeting problems that have consequences for efforts between maintaining assets as state property and pushing many campuses toward privatization. ${ }^{41}$ This policy is considered to be able to shift the role of the state in creating a crucial agency in social change, especially if the state is faced with the challenges of contemporary globalization which rechallenge the existence of Islam in the presence of the state, problems of identity and debate over the nation state.

Every era has different challenges. Now universities are faced with the problem of globalization which requires competition in many aspects. The stakes could not be higher: if the challenges we face are global in scale and transcend national boundaries and traditional academic boundaries, then we must adapt our research and teaching accordingly. Amin Abdullah criticized the terms "act locally" and "think globally". It is intended to act and do around your own environment and environment according to the rules and norms of local traditions and for thinking, for socializing and even for communicating with other societies. has been around since the $1980 \mathrm{~s},{ }^{42}$ this term allows us to adapt and modify institutional development strategies. The global reality that does not allow us to close ourselves and interact in a narrow territorial manner, but also as far as possible global interactions, does not erase our Islamic, national and regional identities. Even stranger, when there is a statement "think and act locally". Furthermore, Amin said, this model shows how confined society is in the global discourse battle. As a result, life feels cramped and interests dwell on internal battles. ${ }^{43}$

Studies on the role of universities in other countries have been developed with a focus on examining the correlation between 
higher education and religious transformation in Muslim societies. For example, Peek reports and explores the process of forming religious identity. ${ }^{44}$ The report reveals the emergence of religion as the most prominent source of personal and social identity for a group of second-generation American Muslims. Peek also describes the three stages of developing religious identity: religion ascribed identity; religion as the chosen identity; and religion as a declared identity. Muslim youth in Canada are committed to maintaining an Islamic lifestyle despite the pressures of conformity to the dominant culture. ${ }^{45}$ Using case studies on Muslim students and parents, this article shows how Muslim students can negotiate and maintain their religious identity in secular public schools.

Among Muslims, the idea of establishing Islamic higher education emerged in the forum of the Al Islam II Majelis Islam A'la Indonesia (MIAI) in 1939. The congress itself was attended by Islamic organizations members of MIAI, including Al Washliyah. The establishment of this Islamic higher education institution was designed to produce intellectual scholars, learners who pursue religious knowledge broadly and deeply, as well as learn general knowledge needed in modern society. From here, Al Washliyah then designed a higher education establishment in Medan. In North Sumatra 1952 the University of North Sumatra (USU) and HKBP Nomensen was established, in 1956, while Islamic scholars and intellectuals who were Masjumi figures here founded UISU. Then, January 24, 1958 was born Al Washliyah University (UNIVA). The founding figures of UNIVA were Haji M. Arsjad Th. Lubis, Haji Adnan Lubis, Udin Sjamsuddin, Haji Muhammad Nurdin, OK. Haji Abdul Aziz, Nukman Sulaiman, Aziz Tanjung, Bahrum Djamil, Abd. Jalil Mhd, H.M. Nurdin, Abdul Jalil Siregar, H.M Husein Abd. Karim, Harun Amin, Asiah Lubis, Zahora Dar, Mhd. Saad. The position of the UNIVA building is on a land area of more than 2 hectares or $25,330 \mathrm{~m} 2$, 
which is in km. 5.5 directions to Tanjung Morawa from Medan, now the location is Jalan Sisingamangaraja. Islam's clashes with leftists also had an impact on gaining this land. The site is land controlled by the Barisan Tani Indonesia (BTI) group which is affiliated with the Indonesian Communist Party (PKI). The peasants rejected the desire of the Al Washliyah organization to buy the land on the grounds that this organization was affiliated with Masyumi. However, through long negotiations the land was finally purchased. Furthermore, the obstacles in the establishment of this university did not stop, especially when the economic recession disrupted national political stability during the guided democracy era of 1959-66. ${ }^{46}$ The era of guided democracy that was made possible was after March 14, 1957, because the state was declared in a state of war where military law was in effect. Second, the party that belongs to the Muslim community MASYUMI (Majelis Shura Muslimin Indonesia) confronted President Soekarno and was threatened with being dissolved, and in many places the detention of Islamic figures took place. Third, land and oil mining issues in the North Sumatra region that have triggered political tensions at the national level.

This socio-political context, of course, affects the conditions of Islamic activity in various regions in Indonesia, including in terms of religious development policies and Islamic education, which is not very beneficial for the ulama who initiated the university. ${ }^{47}$ What's more, Al Washliyah and some of its central figures such as M. Arsjad Th. Lubis and Bahrum Djamil are members of the Masyumi representative constituency. ${ }^{48}$ Bahrum Djamil, in his article, protested the central government's policy of not being so pro-Muslim. In 1953, he referred to official data released by the government which explained the comparison of subsidies provided by the government to schools that looked lame. Neutral schools that are not affiliated with any ideology 
get 27\%, Catholic schools 47\%, Protestant schools 23\%, and meanwhile Islamic schools are 3\%. ${ }^{49}$ This fact has not diminished the enthusiasm of Al Washliyah activists, Bahrum Djamil emphasized;

Dalam serba kekurangan dan kesulitan Al Washlijah tiada hendak membiarkan masa dengan meratap, tetapi insja Allah dengan hasrat bekerdja memenuhi kekurangan2 jang ada itu, jang jatuh...djatuh, jang rebah...rebah, jang hilang...hilang, tetapi Al Washlijah akan Djalan terus, tjita2 itu hendak didjelmakan Al Washlijah suatu bentuk instituut Perguruan Tinggi. Adalah selajaknja setelah Al Washlijah mempunjai tingkat2 madrasah menengah atas mempunjai pula suatu Perguruan Tinggi. ${ }^{50}$

Bahrum Djamil's statement can be interpreted as the weak position of the UNIVA project. This means that UNIVA was built not in an established state, with minimal government support and unfriendly political perceptions. However, the spirit of Islamic teachings in developing science and commitment to struggle are used as capital to continue the ideals of establishing Islamic higher education in North Sumatra. This is a derivation of the Islamic political struggle of Al Washliyah which consists of two fields. First, the political field. The work of developing Islam in this area was manifested in their participation in the Islamic political party, namely Masyumi. Second, the field of social empowerment by establishing educational institutions and social charities. In the early days, several Faculties were opened such as the Sharia Faculty, Teacher Training and Education, Ushuluddin, Tarbiyah and Law. Although at the beginning government support was not enough, in the course of implementing learning, UNIVA and the government could work together. This can be clarified by looking at the UNIVA lecture building which is used as a student study room, also used by the government, namely the Ministry of Religion in the morning for student study rooms for the State Islamic Religion Teacher Education 
program (PGAIN). This program then aims to produce civil servants, namely teachers of Islam, and because this program in the course of UNIVA then becomes a social factory that produces scholars, scholars, socio-religious actors, who play a role not only in times of struggle but also filling independence, their ulama serve people, become civil servants, and control public opinion.

\section{Islamic Authority and Nationalism}

Universities, including Islamic universities in Indonesia have historically not been born in an empty space. Social, political, and even ideological conditions have greatly influenced its birth and development. ${ }^{51}$ Kraince has explored the role of PTAIN in promoting the relationship between the various religious patterns of the Muslim community in the post-Suharto era. He clarified how the progressive nature of the leaders of Islamic higher education, they criticized Muslim intellectual traditions and reformed Islamic thought. ${ }^{52}$ In the establishment of IAIN, now UIN (State Islamic University) Jakarta, for example, there were at least three reasons behind its appearance. First, the reason is to study and develop Islamic religious knowledge to a higher level, which is more systematic and focused. Second, the reason is related to efforts to develop and improve Islamic da'wah activities, so that students and society in general get a better understanding and implementation of Islam. Third, the reasons are ideological and pragmatic in nature; ideological reasons seem to be for the purpose of producing a cadre of scholars and / or teachers, while pragmatic reasons seem to be the goal in producing cadres for bureaucratic personnel,,$^{53}$ such as preparations for people who will sit in the Ministry of Religion of the Republic of Indonesia. Regardless of which dominant factor influences the process of emergence and development, if an 
educational institution wants to progress and develop in a better direction, it must be able to realize and be responsive to the social and political conditions that occur in the surrounding community. Therefore, as a response to the dynamics of the socio-political community life, the output of educational institutions must have a sustainable aspect; meet human needs, especially to improve institutions that enable people to develop their full potential. Islamic higher education institutions must reform their educational paradigm and management to bring more progress to the institution, society and the state. They must apply the concepts of modern education policy, namely autonomy, accountability and professionalism. Their leaders must be able to transform their institutions into leading and reputable institutions that produce graduates who are ready to participate in national development. ${ }^{54}$

In Indonesia, before the state carried out the bureaucratization of Islam, including in the field of higher education, before the emergence of the State Islamic Religious Institute (IAIN) in various cities, Islamic mass organizations led by scholars had established higher education facilities. In North Sumatra, in this case UNIVA. In the chapter of the aims and objectives of the Al Washliyah University Foundation, it is written that this institution was established with the aim of preserving life and the development of Al Washliyah University which is based on Islam and Pancasila and the 1945 Constitution of the Republic of Indonesia and which aims to: a) Prepare scholars and scholars who are responsible having a noble character to serve for the safety of the religion of the nation and state; b) Preparing experts who are capable of holding positions of the State or society who have expertise and skills and advance science; c) Developing science and based on scientific investigation to contribute to the interests of a just and prosperous society. 
The basic point of this stance clearly integrates Islam and nationality. ${ }^{55}$ In addition, this point emphasizes that Islamic groups at that time in the 1950s did not lead to rebellion and division at all, but Islam strengthened the state. Here, Islam and the state work together to strengthen and grow together. ${ }^{56}$ Regarding the chaotic political situation of Islam due to Masjumi's feud with the government, which makes Islam seem not supportive of the state and even supports rebellions in several places, it seems that the scholars of UNIVA are well aware of the importance of integrating Religion and State. The founders of this university never imagined that they would establish a global religious power such as the caliphate, and even the position of thought of the founders of UNIVA did not agree with the formation of a federal or East Sumatra state. Their movement paradigm is based on the concept of moderate Islam, religious moderation, Islam washathiyyah. This concept is a fundamental formula that combines Islam and the nation state. They work alongside Muslims to become Muslims in Indonesia, strengthening their faith and love for their nation. In achieving the first institutional goal: to create scholars, it can be confirmed in the implementation of their learning curriculum in the religious faculty; Sharia, Tarbiyah, Dakwah and Ushuluddin. Here, they studied books written by classical and medieval scholars. Some of the teachers, come from the Al Qismul 'Aly (a program equivalent to senior secondary education) at the Al Washliyah institution, then they continue their higher education to campuses in the Middle East such as Egypt, Baghdad, Makkah, Medina, and Tripoli Libya. Indeed, in the transmission and reform of Islamic education in Indonesia, the teaching network of Middle Eastern alumni is very influential and has long historical roots dating back to at least the 17th century ${ }^{57}$ Hiroko Kinoshita in his research found the al-Azhar alumni network that has played a significant role in the development of Islamic higher education in Indonesia. ${ }^{58}$ 
The existence of this university has encouraged major changes in the social structure of society, they assist the people in increasing literacy, adding community skills when dealing with the state. Islamic values have been integrated with the culture of the Indonesian nation. On a different side, UNIVA through its academic community has worked to help the new government in many ways such as strengthening government bureaucratization, Islamic bureaucratization in public policy regulations at the Ministry of Religion and the Religious Courts, and even being involved in eradicating the PKI. ${ }^{59}$ This campus encourages an advanced form of Islam. ${ }^{60}$ The teachers are important opinion makers in the community, through writings in various daily newspapers, lectures in various recitations and forums. On campus they study the science of kalam, sharia, and Islamic practices and are progressive in educating young Muslims, especially in the religious field.

One of the most influential teachers was Shaykh M. Arsjad Th. Lubis (1908-1972). Mardian Idris in his dissertation on Shaykh Arsjad said that M. Arsjad Th. Lubis had a role in local political history by making the Al Jam'iyatul Washliyah organization and the Masyumi political party as tools for the struggle for Islamic nationalism through three movements; education, preaching, and national politics. ${ }^{61} \mathrm{He}$ is a scholar who studied Islam at the local level and has never been recorder as having studied in the Middle East, mastering jurisprudence, theology, and comparative religion. He was also a Masyumi politician and served as a central committee member in 1953-1954, and a member of the Constituent Assembly from the Masyumi faction from 1956 until it was dissolved in 1960. Arsjad is a republican figure who fully defends the existence of a unitary republic of Indonesia, rejects the East Sumatra state, and oppses the second Dutch aggression in Medan. Arsjad Th. Lubis' thoughts and position 
formed the unique relationship between Al Washliyah and the state. So, UNIVA on the one hand belongs to the Al Washliyah organization and UNIVA supports the existence and programs of the state. However, on the other hand, even thogh the state does not have this educational institution, it is supported and funded by the state. Then, when there was a state promotion of establishing state higher education in North Sumatra, M. Arsjad Th. Lubis did not want to give up UNIVA's assets to be converted into state property on the grounds that Al Washliyah's ideals were different from those state. ${ }^{62}$ So, UNIVA must do what their dreams of themselves. Through this figure of M. Arsjad Th. Lubis, who is also an influential politician from Masyumi in North Sumatra, it can be clarified that UNIVA's ideals are to strengthen community resources, strengthen their Islam and Nationalism, al thought that does not mean that UNIVA belongs to the state.

Another character is Nukman Sulaiman. A scholar born in 1917 in Perbaungan, the son of a royal mufti Serdang Abdul Aziz. Nukman is a very obedient to parents, diligent in worship and studying. He, like many scholars offal Washliyah, was an As'ary, his tasauf followed Al-Ghazâlî, in the Shafii Islamic Figh, ${ }^{63}$ studied fully within the scientific tradition offal Washliyah, and never studied formally in the Middle East. Nukman's figure is phenomenal in the history of UNIVA. ${ }^{64}$ Along with his main job as a civil servant at the Ministry of Religion, his life was devoted to Muslims, Al Washliyah and UNIVA, co-founded and founded universities and was rector for 22 years as rector for five periods from 1965 to $1987 .{ }^{65}$ In the years of his leadership, he has overcome many obstacles, internal organizational conflicts and external political pressure, including the riots of communism. He experienced a dilemma between maintaining the special character of UNIVA which studied Islamic studies but on the 
other hand faced the tendency of the need for secular science scholarships which demanded the presence of the faculties of secular science at UNIVA. Nukman also experienced a period when the influence of UNIVA as a learning destination for madrasa students in various regions in North Sumatra declined due to the establishment of the IAIN here. Among his most influential publications, Nukman Sulaiman is the author of "Peringatan Al Djamijatul Washlijah 1/4 Abad", ${ }^{66}$ which is a relatively complete academic literature on the history of $\mathrm{Al}$ Washliyah to this day, his paper on the law of borrowing the uterus. ${ }^{67}$ In this paper he succeeded in showing a very amazing scientific argument for Islam, where at that time people were disturbed by the phenomenon of borrowing the uterus. ${ }^{68}$

The political reality of Muslims during the Japanese occupation can be seen in Benda's report, which found a polarization of the mindset of Muslims consisting of orthodoxy and reformists. The object's polarization refers to the two major Islamic organizations Muhammadiyah and NU. In that context, the spark of the revival of the role of Islam has been enormous and they have tried to strengthen their political position in welcoming a new independent state in accordance with their political goals. ${ }^{69}$ However, as the style of thinking of the Al Washliyah ulama figures, of course they do not want to be trapped in a polemic against one another. This organization prefers a strategic step how to get out of this trap by strengthening evolutionist change agendas, slowly and optimistically. According to Nukman Sulaiman, we don't need to be trapped by the groupings made by Harry J. Benda. It is better to find out why Muslims are deemed incapable of formulating their political goals. ${ }^{70}$ In the end, this is indeed the case, various arguments have emerged against the weakness of Muslims in formulating political goals, both in the short and long term, so that the consistency of future strategic 
steps is blurred. Nukman Sulaiman did not believe that strengthening the political goals of Islam had to be through party politics, but he strongly believed that the political goals of Islam could be achieved through the implementation of Islamic education from basic to higher education. ${ }^{71}$ In other words, this is the political form of UNIVA Islamic education that changes gradually, slowly, evolutionistically, and consistently. ${ }^{72}$ In short, UNIVA's national politics is the politics of educating the lives of the nation's children which in turn will become agents of social change in society and can fill bureaucratic pockets that strengthen the existence of the nation state.

It is noteworthy that UNIVA's conceptual mindset was influenced by its early founders who generally had domestic learning experience and were not directly connected to teaching from the Middle East. M. Arsjad Th. Lubis and Nukman Sulaiman, as previously explained, are examples of getting a model of a style of thought with a distinctive Islamic-nationality formation. Maintain a balance between religious-republican and Islamicnationality in the implementation of Islamic higher education.

\section{Conclusion}

This study is a limited elaboration of UNIVA in a 1950s setting with the hope of re-reading critically of history and understanding the socio-political context that surrounds it can lead readers to efforts to formulate contemporary work and structure future orientations. In this article I have clarified how the role of Islamic scholarship and the role of nationality have been played by UNIVA. Al Washliyah University in the trajectory of modern Indonesian history has succeeded in building a dominant discourse in society, creating Islamic scientific authority, ulama and its teaching to the Southeast Asian level. In addition, 
the existence of the university and its relations with politics have shown an example that should be maintained, especially in terms of national commitment, creating Islamic intellectual cadres who are persistent in fighting for the religion and state of Indonesia. Second, this article has also opened an analysis of how the Islamic scientific tradition that was built and developed by UNIVA scholars as a foundation for Islamic educators, actors of Islamic universities in promoting democratization and nationality, creating social cohesion. The presence of the Islamic movement in the last few decades in Indonesia, the development of democratization, and the information technology revolution, could be a new challenge for the existence of the institution in the future. Therefore, this situation opens space for further discussion, especially how to maintain Islamic scientific authority and nationhood in the vortex of the new wave of globalization.

\section{References}

Abdullah, M. Amin. "Islamic Studies in Higher Education in Indonesia: Challenges, Impact and Prospects for the World Community.” Al-Jamiah 55, no. 2 (2017): 391-426. https:/ /doi.org/10.14421/ajis.2017.552.391-426.

Abdullah, Taufik. Indonesia: Towards Democracy. Institute of Southeast Asian Studies, 2009.

Asari, Hasan. "'Ulama' Training and Modernizing Al Washliyah Madrasah." Journal of Contemporary Islam and Muslim Societies, 2019. https://doi.org/10.30821/jcims.v3i2.6323.

Asari, Hasan, and Zainal Abidin. "Kitab Kuning and Training of 'Ulama': The Experience of Madrasah Al Qismul Ali Jalan Ismailiyah Medan.” MIQOT:Jurnal Ilmu-ilmu Keislaman 44, no. 1 (2020): 93-115. 
Azra, Azyumardi. "Indonesian Higher Education: From Public Good to Privatization." Journal of Asian Public Policy 1, no. 2(2008):139-47.https://doi.org/10.1080/17516230802094411.

—. The Origins of Islamic Reformism in Southeast Asia: Networks of Malay-Indonesian and Middle Eastern'Ulam?'in the Seventeenth and Eighteenth Centuries. Ohio: University of Hawaii Press, 2004.

Benda, Harry J. The Crescent and the Rising Sun: Indonesian Islam under the Japanese Occupation 1942-1945. The Hague Hoeve, 1958.

Bruinessen, Martin Van, ed. Contemporary Developments in Indonesian Islam: Explaining the 'Conservative Turn.' ISEAS Publishing, 2013.

Djamil, Bahrum. Batu Demi Batu Di Bawah Panas Yang Terik. Medan: Ma'had Mu'allimin Al Washliyah, 1992.

El-Hadidhy, Syahrul AR. et.al. Pendidikan Ke Al-Washliyahan. Medan: MPK Al-Jam'iyatul Washliyah, 2005.

Feith, Herbert. Pemilu 1955 Di Indonesia. Jakarta: Kepustakaan Populer Gramedia, 1999.

—. Politics of Economic Decline." Sukarno’s Guided Indonesia, 1967.

- The Decline of Constitutional Democracy in Indonesia. Ithaca: Cornell Modern Indonesia Project.” Southeast Asia Program, Cornell University Press, 1962.

Fogg, Kevin W. "Indonesian Islamic Socialism and Its South Asian Roots.” Modern Asian Studies 53, no. 6 (2019): 173661.

—. "State and Islamic Education Growing into Each Other in Indonesia." In Southeast Asian Education in Modern History, 178-93. Routledge, 2018.

Hamka. Merantau Ke Deli. Jakarta: Gema Insani Press, 2017. 
Hanum, Lathifah. "Perempuan Di Lembaga Pendidikan Al Jam'iyatul

Washliyah." Journal of Contemporary Islam and Muslim Societies 2, no. 1 (2018): 29-49.

Hasanuddin, Chalijah. Al-Jam'iyatul Washliyah Api Dalam Sekam. Bandung: Pustaka, 1988.

Idris, Mardian. "Ulama Dan Politik: Studi Terhadap Pemikiran Dan Kiprah Sosial Politik Syekh M. Arsyad Thalib Lubis (1908-1972).” UIN Syarif Hidayatullah Jakarta, 2020.

Irwansyah. "Pemikiran Nukman Sulaiman Terhadap Hukum Meminjamkan Rahim Untuk Kandungan Bayi.” Pascasarjana UIN-SU, 2013.

Ja'far, Ja'far. “Al Jam'iyatul Washliyah Dan Pelestarian Akidah Ahl Sunnah Wa Al-Jama'ah Di Indonesia.” ISLAMICA: Jurnal Studi Keislaman 14, no. 1 (2019). https://doi.org/ 10.15642/islamica.2019.14.1.54-81.

—. "Al Jam"iyatul Washliyah dan Kepemimpinan Non Muslim Dan Perempuan.” AHKAM: Jurnal Ilmu Syariah 17, no. 2 (2017). http://journal.uinjkt.ac.id/index.php/ahkam/article/ view/5204.

_. "Merantau Demi Republik: Kehidupan Dan Perjuangan Ismail Banda (1909-1951)." Islamijah: Journal of Islamic Social Sciences 1, no. 2 (2020): 136-61. https://doi.org/ 10.30821/islamijah.v1i2.7181.

__ "Pemikiran Politik Islamisme Moderat Al Jam'iyatul Washliyah." Al-A'raf: Jurnal Pemikiran Islam Dan Filsafat, 2019. https:/ /doi.org/10.22515/ajpif.v16i2.1762.

__. "Peran Al Jam'iyatul Washliyah Dalam Merevitalisasi Madhhab Shafi'i Di Era Kontemporer." Justicia Islamica, 2016. https:/ /doi.org/10.21154/justicia.v13i1.451.

—. "Peran M. Arsjad Th. Lubis Dalam Pengembangan IlmuIlmu Keislaman." Dialogia: Jurnal Studi Islam Dan Sosial 18, no. 2 (2020): 355-76. 
_. " "Tradisi Intelektual Ulama Mandailing Abad Ke-20: Dedikasi Dan Karya-Karya Yusuf Ahmad Lubis (1912-1980).” Islamijah: Journal of Islamic Social Sciences 1, no. 2 (2020): 225-47. https://doi.org/10.30821/islamijah.v1i3.7342.

—. "Ulama Mandailing Awal Abad Ke-20: Gerakan Religius Dan Politik Abdurrahman Sjihab (1910-1955).” Islamijah: Journal of Islamic Social Sciences 1, no. 1 (2020): 1-25. https://doi.org/10.30821/islamijah.v1i1.7155.

__. "Respons Dewan Fatwa Al Jam'iyatul Washliyah Terhadap Isu Akidah Dan Syariah Di Era Global.” Al-Manahij:Jurnal Kajian Hukum Islam,2017. https://doi.org/10.24090/mnh.v10i1.919.

Kinoshita, Hiroko. "Islamic Higher Education in Contemporary Indonesia: Through The Islamic Intellectuals of Al-Azharite Alumni." Kyoto Working Paper on Areas Studies JSPS Global COE Series 81, In Search of Humanospherevin Asia and Africa. Vol. 79. 81. Kyoto Japan, 2009. https:// doi.org/10.1017/CBO9781107415324.004.

Kraince, Richard G. "Islamic Higher Education and Social Cohesion in Indonesia." Prospects 37, no. 3 (2007): 345-56. https:// doi.org/10.1007/s11125-008-9038-1.

Lazuardi, Muhammad Fijar, and Yety Rochwulaningsih. "Kontestasi Partai Politik Di Sumatera Utara Pada Masa Demokrasi Liberal 1952-1955” 1, no. 1 (2020): 11-21.

Lukens-Bull, Ronald. Islamic Higher Education in Indonesia: Continuity and Conflict. Springer, 2013.

—. "Negotiating Continuity And Change In Indonesian Islamic Higher Education.” EDUKASI:Jurnal Penelitian Pendidikan Agama Dan Keagamaan 11, no. 2 (2013): 141-49. https:// doi.org/10.32729/edukasi.v11i2.430.

_. "The Political Use of Islamic Variation in Indonesian Islamic Higher Education.” Jurnal Pendidikan Islam 2, no. 2 (2016): 193. https://doi.org/10.15575/jpi.v2i2.786. 
Menchik, Jeremy. Islam and Politics in Indonesia: The Masyumi Party between Democracy and Integralism by Rémy Madinier. Indonesia. Vol. 101, 2016. https://doi.org/10.1353/ind.2016.0014.

Noor, Firman. "Islamic Party and Pluralism: The View and Attitude of Masyumi towards Pluralism in Politics (19451960).” Al-Jamiah 54, no. 2 (2016): 273-310. https://doi.org/ 10.14421/ajis.2016.542.273-310.

Peek, Lori. "Becoming Muslim: The Development of a Religious Identity.” Sociology of Religion 66, no. 3 (2005): 215. https:/ /doi.org/10.2307/4153097.

Pelzer, Karl. J. Planters against Peasants. Leiden, The Netherlands: Martinus Nijhoff, 1982.

Pulungan, Abbas. "Nahdlatul Ulama Di Luar Jawa: Perkembangan Di Tanah Mandailing.” Journal of Contemporary Islam and Muslim Societies 2, no. 1 (2018): 91-217.

Rasyidin, Al. "Islamic Organizations in North Sumatra: The Politics of Initial Establishment and Later Development." Journal of Indonesian Islam 10, no. 1 (2016): 63-88. https:/ /doi.org/10.15642/JIIS.2016.10.1.63-88.

Reid, Anthony and John Stanhope. Sumatera: Revolusi Dan Elit Tradisional. Komunitas Bambu, 2011.

Ricklefs, M.C. A History of Modern Indonesia: C. 1300 to the Present. London: Mcmillan, 1981.

Riza, Faisal. "Contesting the Space in Indonesia: A Case From Al-Washliyah in North Sumatra." Afkaruna 10, no. 2 (2014): 149-62. https://doi.org/10.18196/aiijis.2014.0035.149-162.

—. "Gerakan Pemberdayaan Perempuan Islam: Muslimat AlWashliyah Di Sumatera Timur 1930-1945” 15, no. 2 (2016): 189-202. https://doi.org/http://dx.doi.org/10.24014/ marwah.v15i2.2647.

Said, Muhammad M., Nuryani Muhammad, and Kaviyarasu Elangkovan. "The Continuity and Change of Indonesia's Islamic Higher Educational Institutions in the Amid of 
Educational Policy Change." Asian Social Science 10, no. 6 (2014): 71-80. https://doi.org/10.5539/ass.v10n6p71.

Saragih, Aliman. "Kontribusi Al Jam'iyatul Washliyah Terhadap Kemerdekaan Indonesia (1930-1950).” MIQOT:Jurnal IlmuIlmu Keislaman 40, no. 1 (2016).

Siddik, Dja'far, and Rosnita. “Gerakan Pendidikan Al-Washliyah Di Sumatera Utara.” Ulumuna 18, no. 1 (2014): 59-80.

Sulaiman, Nukman. Peringatan Al Djamijatul Washlijah 1/4 Abad. Medan: Pengurus Besar Al Djamijatul Washlijah, 1956.

Sulaiman, Nukman. Lustrum VI Universitas Al Washliyah 18 Mei 1958-18 Mei 1988. Medan: UNIVA, 1988.

—. Peringatan Abad Al Jamijatul Washlijah. Medan: Pengurus Besar Al-Djamijatul Washlijah, 1956.

—. Riwayat Hidup.” In Nukman Sulaiman, Seminar Sehari Tentang Meminjamkan Rahim Untuk Kandungan Bayi. Medan: Yaspen UNIVA, 1987.

Syahnan, Mhd., Asrul Asrul, and Ja'far Ja'far. “Intellectual Network of Mandailing and Haramayn Muslim Scholars in the Mid-19th and Early 20th Century". TEOSOFI: Jurnal Tasawuf dan Pemikiran Islam 9, no. 2 (December 1, 2019): 257-281.

Syahnan, Mhd., Ja'far Ja'far, and Muhammad Iqbal. 'Ulama and Radicalism in Contemporary Indonesia: Response of Al Washliyah's Ulama on Radicalism.” Ahkam: Jurnal Ilmu Syariah, 21, no 1 (2021): 89-110.

Thaib, M. Hasballah, and Zamakhsyari Hasballah. Bersama Almarhum Prof. Drs. H. Nukman Sulaiman. Jakarta: Perdana, 2012.

Thaib, M. Hasballah. Universitas Al Washliyah Medan Lembaga Pengkaderan Ulama Di Sumatera Utara. Medan: UNIVA, 1993.

Zahara, Rita. "Sejarah Universitas Al-Washliyah (UNIVA) Medan 1958-2010.” Pascasarjana IAIN Sumatera Utara, 2011. 
Zine, Jasmin. "Muslim Youth in Canadian Schools: Education and the Politics of Religious Identity." Anthropology and Education Quarterly, American Anthropological Association 32, no. 4(2001):399-423. https://doi.org/10.1525/aeq.2001.32.4.399.

\section{Interview}

Interview with M. Hasballah Thaib in Medan.

Interview with Halfian Lubis, The Rector of UNIVA Medan in Medan. 


\section{Endnotes:}

${ }^{1}$ Kevin W. Fogg, "Indonesian Islamic Socialism and Its South Asian Roots," Modern Asian Studies 53, no. 6 (2019): 1736-61.

${ }^{2}$ Martin Van Bruinessen, ed., Contemporary Developments in Indonesian Islam: Explaining the 'Conservative Turn' (ISEAS Publishing, 2013).

${ }^{3}$ Abbas Pulungan, "Nahdlatul Ulama Di Luar Jawa: Perkembangan Di Tanah Mandailing," Journal of Contemporary Islam and Muslim Societies 2, no. 1 (2018): 91-217.

${ }^{4}$ Nukman Sulaiman, Lustrum VI Universitas Al Washliyah 18 Mei 1958-18 Mei 1988 (Medan: UNIVA, 1988).

${ }^{5}$ M. Hasballah Thaib, Universitas Al Washliyah Medan Lembaga Pengkaderan Ulama Di Sumatera Utara (Medan: UNIVA, 1993).

${ }^{6}$ Rita Zahara, "Sejarah Universitas Al-Washliyah (UNIVA) Medan 1958-2010” (Pascasarjana IAIN Sumatera Utara, 2011).

${ }^{7}$ Dja'far Siddik and Rosnita, "Gerakan Pendidikan Al-Washliyah Di Sumatera Utara," Ulumuna 18, no. 1 (2014): 59-80.

${ }^{8}$ Herbert Feith, The Decline of Constitutional Democracy in Indonesia (Ithaca: Cornell Modern Indonesia Project.” Southeast Asia Program, Cornell University Press, 1962).

9 Taufik Abdullah, Indonesia: Towards Democracy (Institute of Southeast Asian Studies, 2009), 194.

${ }^{10}$ Ja'far Ja'far, “Al Jam'iyatul Washliyah dan Kepemimpinan Non Muslim Dan Perempuan,” AHKAM:Jurnal Ilmu Syariah 17, no. 2 (2017), http://journal.uinjkt.ac.id/ index.php/ahkam/article/view/5204.

${ }^{11}$ Ja'far Ja'far, "Merantau Demi Republik: Kehidupan Dan Perjuangan Ismail Banda (1909-1951)," Islamijah: Journal of Islamic Social Sciences 1, no. 2 (2020): 136-61, https://doi.org/10.30821/islamijah.v1i2.7181.

${ }^{12}$ Ja'far Ja'far, "Peran M. Arsjad Th. Lubis Dalam Pengembangan Ilmu-Ilmu Keislaman,” Dialogia: Jurnal Studi Islam Dan Sosial 18, no. 2 (2020): 355-76.

${ }^{13}$ Ja'far Ja'far, "Ulama Mandailing Awal Abad Ke-20: Gerakan Religius Dan Politik Abdurrahman Sjihab (1910-1955)," Islamijah:Journal of Islamic Social Sciences 1, no. 1 (2020): 1-25, https://doi.org/10.30821/islamijah.v1i1.7155.

${ }^{14}$ Ja'far Ja'far, "Tradisi Intelektual Ulama Mandailing Abad Ke-20: Dedikasi Dan Karya-Karya Yusuf Ahmad Lubis (1912-1980)," Islamijah: Journal of Islamic Social Sciences 1, no. 2 (2020): 225-47, https://doi.org/10.30821/islamijah.v1i3.7342.

${ }^{15}$ Nukman Sulaiman, Peringatan Al Djamijatul Washlijah Abad (Medan: Pengurus Besar Al Djamijatul Washlijah, 1956).

${ }^{16}$ Ja'far Ja'far, “Al Jam'iyatul Washliyah Dan Pelestarian Akidah Ahl Sunnah Wa Al-Jama'ah Di Indonesia,” ISLAMICA: Jurnal Studi Keislaman, 2019, https:// doi.org/10.15642/islamica.2019.14.1.54-81. 
${ }^{17}$ Ja'far Ja'far, “Peran Al Jam'iyatul Washliyah Dalam Merevitalisasi Madhhab Shafi'i Di Era Kontemporer,” Justicia Islamica, 2016, https://doi.org/10.21154/justicia.v13i1.451.

${ }^{18}$ Chalijah Hasanuddin, Al-Jam'iyatul Washliyah Api Dalam Sekam (Bandung: Pustaka, 1988).

${ }^{19}$ Syahrul AR. El-Hadidhy et al., Pendidikan Ke Al-Washliyahan (Medan: MPK Al-Jam'iyatul Washliyah, 2005).

${ }^{20}$ Aliman Saragih, "Kontribusi Al Jam'iyatul Washliyah Terhadap Kemerdekaan Indonesia (1930-1950),” MIQOT: Jurnal Ilmu-Ilmu Keislaman 40, no. 1 (2016).

${ }^{21}$ Faisal Riza, "Contesting the Space in Indonesia: A Case From Al-Washliyah in North Sumatra," Afkaruna 10, no. 2 (2014): 149-62, https://doi.org/10.18196/ aiijis.2014.0035.149-162.

${ }^{22}$ Al Rasyidin, "Islamic Organizations in North Sumatra: The Politics of Initial Establishment and Later Development," Journal of Indonesian Islam 10, no. 1 (2016): 63-88, https://doi.org/10.15642/JIIS.2016.10.1.63-88.

${ }^{23} \mathrm{Ja}$ 'far Ja'far, "Respons Dewan Fatwa Al Jam'iyatul Washliyah Terhadap Isu Akidah Dan Syariah Di Era Global,” Al-Manahij: Jurnal Kajian Hukum Islam, 2017, https://doi.org/10.24090/mnh.v10i1.919.

${ }^{24}$ Hasan Asari and Zainal Abidin, "Kitab Kuning and Training of 'Ulama': The Experience of Madrasah Al Qismul Ali Jalan Ismailiyah Medan.” MIQOT: 44, No. 1 (2020): 93-115.," MIQOT: Jurnal Ilmu-IImu Keislaman 44, no. 1 (2020): 93115.

${ }^{25}$ Hasan Asari, “'Ulama' Training and Modernizing Al Washliyah Madrasah," Journal of Contemporary Islam and Muslim Societies, 2019, https://doi.org/10.30821/ jcims.v3i2.6323.

${ }^{26}$ Lathifah Hanum, "Perempuan Di Lembaga Pendidikan Al Jam'iyatul Washliyah," Journal of Contemporary Islam and Muslim Societies 2, no. 1 (2018): 29-49.

${ }^{27}$ Faisal Riza, "Gerakan Pemberdayaan Perempuan Islam: Muslimat Al-Washliyah Di Sumatera Timur 1930-1945” 15, no. 2 (2016): 189-202, https://doi.org/http:// dx.doi.org/10.24014/marwah.v15i2.2647.

${ }^{28}$ Feith, The Decline of Constitutional Democracy in Indonesia.

${ }^{29}$ M.C. Ricklefs, A History of Modern Indonesia: C. 1300 to the Present (London: Mcmillan, 1981).

${ }^{30}$ Abdullah, Indonesia: Towards Democracy.

${ }^{31}$ Hamka, Merantau Ke Deli (Jakarta: Gema Insani Press, 2017).

${ }^{32}$ Muhammad Fijar Lazuardi and Yety Rochwulaningsih, "Kontestasi Partai Politik Di Sumatera Utara Pada Masa Demokrasi Liberal 1952-1955” 1, no. 1 (2020): 11-21.

${ }^{33}$ Anthony John Stanhope Reid, Sumatera: Revolusi Dan Elit Tradisional (Komunitas Bambu, 2011).

${ }^{34}$ Herbert Feith, Pemilu 1955 Di Indonesia (Jakarta: Kepustakaan Populer Gramedia, 1999), 44. 
${ }^{35}$ Firman Noor, "Islamic Party and Pluralism: The View and Attitude of Masyumi towards Pluralism in Politics (1945-1960)," Al-Jamiah 54, no. 2 (2016): 273-310, https://doi.org/10.14421/ajis.2016.542.273-310.

${ }^{36}$ Jeremy Menchik, Islam and Politics in Indonesia: The Masyumi Party between Democracy and Integralism by Rémy Madinier, Indonesia, vol. 101, 2016, https:// doi.org/10.1353/ind.2016.0014.

${ }^{37}$ Riza, "Gerakan Pemberdayaan Perempuan Islam: Muslimat Al-Washliyah Di Sumatera Timur 1930-1945.”

${ }^{38}$ Karl. J. Pelzer, Planters against Peasants (Leiden, The Netherlands: Martinus Nijhoff, 1982).

${ }^{39}$ Muhammad M. Said, Nuryani Muhammad, and Kaviyarasu Elangkovan, "The Continuity and Change of Indonesia's Islamic Higher Educational Institutions in the amid of Educational Policy Change," Asian Social Science 10, no. 6 (2014): 71-80, https://doi.org/10.5539/ass.v10n6p71.

${ }^{40}$ Ronald Lukens-Bull, "Negotiating Continuity And Change In Indonesian Islamic Higher Education," EDUKASI: Jurnal Penelitian Pendidikan Agama Dan Keagamaan 11, no. 2 (2013): 141-49, https://doi.org/10.32729/edukasi.v11i2.430.

${ }^{41}$ Azyumardi Azra, "Indonesian Higher Education: From Public Good to Privatization,” Journal of Asian Public Policy 1, no. 2 (2008): 139-47, https://doi.org/ 10.1080/17516230802094411.

${ }^{42}$ M. Amin Abdullah, "Islamic Studies in Higher Education in Indonesia: Challenges, Impact and Prospects for the World Community," Al-Jamiah 55, no. 2 (2017): 391-426, https://doi.org/10.14421/ajis.2017.552.391-426.

${ }^{43}$ Abdullah.

${ }^{44}$ Lori Peek, "Becoming Muslim: The Development of a Religious Identity," Sociology of Religion 66, no. 3 (2005): 215, https://doi.org/10.2307/4153097.

${ }^{45}$ Jasmin Zine, "Muslim Youth in Canadian Schools: Education and the Politics of Religious Identity," Anthropology and Education Quarterly, American Anthropological Association 32, no. 4 (2001): 399-423, https://doi.org/10.1525/aeq.2001.32.4.399.

${ }^{46}$ Herbert Feith, Politics of Economic Decline.” Sukarno’s Guided Indonesia, 1967.

${ }^{47}$ Bahrum Djamil, Batu Demi Batu Di Bawah Panas Yang Terik (Medan: Ma'had Mu'allimin Al Washliyah, 1992).

${ }^{48}$ Ja'far Ja'far, "Pemikiran Politik Islamisme Moderat Al Jam'iyatul Washliyah," Al-A'raf:Jurnal Pemikiran Islam Dan Filsafat 16, no. 2 (2019), https://doi.org/10.22515/ ajpif.v16i2.1762.

${ }^{49}$ Nukman Sulaiman, Peringatan Al Djamijatul Washlijah 1/4 Abad (Medan: Pengurus Besar Al-Djamijatul Washlijah, 1956), 24.

${ }^{50}$ Sulaiman., 25

${ }^{51}$ Ronald Lukens-Bull, "The Political Use of Islamic Variation in Indonesian Islamic Higher Education,” Jurnal Pendidikan Islam 2, no. 2 (2016): 193, https:// doi.org/10.15575/jpi.v2i2.786. 
${ }^{52}$ Richard G. Kraince, "Islamic Higher Education and Social Cohesion in Indonesia,” Prospects 37, no. 3 (2007): 345-56, https://doi.org/10.1007/s11125-0089038-1.

${ }^{53}$ Ronald Lukens-Bull, Islamic Higher Education in Indonesia: Continuity and Conflict (Springer, 2013).

${ }^{54}$ Muhammad Said and Elangkovan, "The Continuity and Change of Indonesia's Islamic Higher Educational Institutions in the amid of Educational Policy Change."

${ }^{55}$ Interview with Halfian Lubis, 18 July 2020.

${ }^{56}$ Kevin W Fogg, "State and Islamic Education Growing into Each Other in Indonesia," in Southeast Asian Education in Modern History (Routledge, 2018), 178-93.

${ }^{57}$ Azyumardi Azra, The Origins of Islamic Reformism in Southeast Asia: Networks of Malay-Indonesian and Middle Eastern'Ulam?'in the Seventeenth and Eighteenth Centuries (Ohio: University of Hawaii Press, 2004). See also Mhd. Syahnan; Asrul Asrul, and Ja'far Ja'far, "Intellectual Network of Mandailing and Haramayn Muslim Scholars in the Mid-19th and Early 20th Century." TEOSOFI: Jurnal Tasawuf dan Pemikiran Islam 9, no. 2 (December 1, 2019): 257-281.

${ }^{58}$ Hiroko Kinoshita, "Islamic Higher Education in Contemporary Indonesia: Through The Islamic Intellectuals of Al-Azharite Alumni,” Kyoto Working Paper on Areas Studies JSPS Global COE Series 81, In Search of Humanospherevin Asia and Africa, vol. 79, 81 (Kyoto Japan, 2009), https://doi.org/10.1017/CBO9781107415324.004.

${ }^{59}$ Interview with M. Hasballah Thaib, July 18, 2020.

${ }^{60}$ Interview with Halfian Lubis, July 18, 2020.

${ }^{61}$ Mardian Idris, "Ulama Dan Politik: Studi Terhadap Pemikiran Dan Kiprah Sosial Politik Syekh M. Arsyad Thalib Lubis (1908-1972)” (UIN Syarif Hidayatullah Jakarta, 2020).

${ }^{62}$ Interview with M. Hasballah Thaib 18 July 2020.

${ }^{63}$ M. Hasballah Thaib and Zamakhsyari Hasballah, Bersama Almarhum Prof. Drs. H. Nukman Sulaiman (Jakarta: Perdana, 2012).

${ }^{64}$ Interview with M. Hasballah Thaib 18 July 2020.

${ }^{65}$ Zahara, "Sejarah Universitas Al-Washliyah (UNIVA) Medan 1958-2010."

${ }^{66}$ Sulaiman, Peringatan 1/4 Abad Al Jamijatul Washlijah.

${ }^{67}$ Nukman Sulaiman, "Riwayat Hidup.” In Nukman Sulaiman, Seminar Sehari Tentang Meminjamkan Rahim Untuk Kandungan Bayi (Medan: Yaspen UNIVA, 1987).

${ }^{68}$ Irwansyah, "Pemikiran Nukman Sulaiman Terhadap Hukum Meminjamkan Rahim Untuk Kandungan Bayi” (Pascasarjana UIN-SU, 2013).

${ }^{69}$ Harry J Benda, The Crescent and the Rising Sun: Indonesian Islam under the Japanese Occupation 1942-1945. (The Hague Hoeve, 1958). For the most recent study on dynamics of Al Washliyah's Ulama Response to contemporary social and 
political issues, see Mhd. Syahnan, Ja'far Ja'far and Muhammad Iqbal, "Ulama and Radicalism in Contemporary Indonesia: Response of Al Washliyah's Ulama on Radicalism," Ahkam: Jurnal Ilmu Syariah 21, no. 1 (2021).

${ }^{70}$ Thaib and Hasballah, Bersama Almarhum Prof. Drs. H. Nukman Sulaiman.

${ }^{71}$ Interview with M. Hasballah Thaib, July 18, 2020

${ }^{72}$ Interview with Halfian Lubis, July 18, 2020 